\title{
Measuring the Impact of Oil Prices and Exchange Rate Shocks on Inflation: Evidence from India
}

\author{
Akhil SHARMA*, Abdul RISHAD ${ }^{* *}$, Sanjeev GUPTA ${ }^{* * *}$
}

Received: December 11, 2018. Revised: July 29, 2019. Accepted: August 24, 2019.

\begin{abstract}
The purpose of this study is to examine the long-run and short-run impact of crude oil price and exchange rate shocks on domestic inflation in India within the framework of the Autoregressive Distributed Lag (ARDL) model. The results show that the exchange rate and oil price shocks significantly influence domestic inflation during the study period (April 1994 to February 2018). Further, the breakpoint unit root test revealed the severe impact of the 2008 financial crisis on inflation in India. The findings show that any move to scale down fuel subsidies will escalate cost-push inflation severely, as the country is an energy-dependent economy. So, policymakers shall stabilise the impact of these shocks through suitable monetary policy actions.
\end{abstract}

Key Words: Oil price, exchange rate, inflation, ARDL, India.

JEL Classification: E31, F31, Q48.

UDC: 339.72

DOI: https://doi.org/10.17015/ejbe.2019.024.03

\footnotetext{
* Doctoral Research Fellow, Department of Accounting \& Finance, Central University of Himachal Pradesh, Dharamshala-Himachal Pradesh, India. Email: 1990akhilsharma@gmail.com.

** Doctoral Research Fellow, Department of Accounting \& Finance, Central University of Himachal Pradesh, Dharamshala-Himachal Pradesh, India. Email: ktdahsir@gmail.com.

*** Professor, School of Business and Management Studies, Central University of Himachal Pradesh, Dharamshala-Himachal Pradesh, India. Email: sanjeevguptaeco@gmail.com.
} 


\section{Introduction}

The exchange rate and oil price pass-through effect and its influence on economic activities, especially in developing economies, is always a nightmare for policymakers (Neely \& Rapach, 2011). In energy-dependent economies, exchange rate and oil price shocks influence the economic growth and act as a vital cause of inflation, which ultimately destabilizes the monetary and financial system of the economy (McKillop, 2004; Mirdala, 2014).

Economists explained oil price fluctuation as a key source of inflation in emerging economies (Blanchard \& Gali, 2007; Blanchard \& Riggi, 2013; Domaç \& Yücel, 2005). As petroleum products are vital input for the production process, any unfavourable movement in oil prices directly passed to the cost of petroleum products causes an increase in the cost of energy. This forces the industry to increase the price, reduce output, and investment. These incidents create cost-push inflation (Jin, 2008). From the consumer's perspective, oil price shocks enhance the energy consumption bill, which has an adverse effect on their disposable income. Moreover, the secondround effect of oil prices on goods and services further worsens the general price level. Some researchers argued that such shocks only have an impact in short-run (Cunado \& Gracia, 2005). While researches like Rautava (2004) argue that it has both long-run as well as short-run effect.

The exchange rate fluctuation influences inflation generally through import prices. It has two stages. In the first stage, exchange rate fluctuations transmit to import price, whereas in the second stage import price transfer to wholesale and consumer prices in the prevailing economic conditions (Yanamandra, 2015). Existing economic conditions and source of exchange rate volatility play an inevitable role in determining the degree of influence of exchange rate on inflation. A weaker exchange rate may enhance inflation expectation and creates some artificial inflation in the market. The vulnerability caused by the impact of exchange rate on inflation can be explosive in an economy with a considerable trade deficit (Senadza \& Diaba, 2017). The impact will be severe if such economies are importing oil and other basic input for industrial production. An expanded monetary policy to enhance economic activity will further aggravate the condition.

Inflation transmitted through exchange rate fluctuation received attention after the failure of the Bretton Woods system in 1971. Similarly, oil price shocks in 1973-74 and $1979-80$ and the resultant economic instability also motivated researchers to explore the connection between those variables (Jalles, 2009). Most of these studies emphasised that oil price shock in 1990 and the energy crisis in 2000 brought in inflation and economic instability to most of the energy-dependent economies. Moreover, these shocks further accelerated the magnitude of the domestic economic problems like unemployment and monetary instability. Countries tightened their monetary policy, which caused a slump in economic growth and development to protect the economy from possible hazards. Further, the increased 
interest rate attracted more capital inflow inducing currency appreciation, which in turn caused a decline in export (Peersman, 2011).

After the adoption of a managed floating regime, India was much concerned about the external competitiveness of Rupee, and the exchange rate pass-through effects and resulting inflation. Similarly, unfavorable movement in oil prices influences energy inflation in India, as the country has an energy-dependent economy. Since there is a high demand for petroleum products, (for instance, around $85 \%$ of India's petroleum demand is met through crude oil import, and this constitutes approximately $9.1 \%$ of the global oil export value in 2016 (IPNG, 2017; Khullar, 2018) any surge in oil price contributes to core inflation and further worsen the condition. Since oil contracts are settled in USD, it also fuels the issue in the form of transaction exposure, where the country has a limited amount of foreign exchange resources. So, an unfavourable movement in oil prices accelerates price level and worsens the domestic economic condition.

Inflation in the global market often seeps through currency fluctuations and oil price hike into the domestic market, which is inevitable for a transition economy like India. Such instances of inflation are not easy to control with traditional monetary policy actions. RBI's recent shift to inflation targeting policy justifies this perspective.

Several studies discussed the impact of exchange rate and oil price movement on inflation in industrialised economies. But there is a dearth of similar studies from Emerging Market Economies (EMEs), especially examining the Indian scenario. Most of them focus mainly on the exchange rate pass-through effect and the impact of other macroeconomic variables on inflation.

The remainder of the paper is organised as follows: Section 2 deals with existing theoretical and empirical studies; section 3 presents the data and methodology, while section 4 and 5 explain the empirical results and concludes the arguments respectively.

\section{Review of Empirical Studies}

The multifaceted and far-reaching impacts of inflation have motivated economists and policymakers to examine the dimensions of its influence on other economic variables. The negative impact of inflation on economic growth and development is also usually examined for the formulation and implementation of appropriate policies. Though these elements are country-specific and time-specific, certain common policy approaches are executed in many economies. For instance, the managed floating exchange rate system assumes that the exchange rate fluctuation may induce inflation in the economy in the absence of intervention. Similarly, policies which regulate import are not just meant to protect domestic industry, but also to insulate the economy from 'imported inflation.'

Crude oil, which is an 'essential' input in the production cycle of many consumer goods, is an influential factor that decides the price of goods. An undesirable oil price 
fluctuation not only reduces the revenue but also increases the cost of production, which results in a price hike and cost-push inflation. It further leads to the deterioration of the global competitiveness of the economy, which may create further issues like excessive depreciation of the domestic currency, inducing further inflation. Moreover, its relationship with the transportation and energy sector also influence the price level directly. Several academic studies have widely established the inter-relationship between the oil prices, price of goods and price level. This relationship was very strong during 1970 and 1990s, because of the oil price shock, but vanished in the mid-1980s (Sek, Teo, \& Wong, 2015). Globalisation of the EMEs, development of an alternative source of energy, and development of energyefficient technologies might have influenced it (Shahbaz, Mallick, Mahalik \& Sadorsky, 2016).

Recent studies from different economies found a strong linkage between oil price shocks and price level changes (Abounoori, Nazarian, \& Amiri, 2014; Onoh, 2017; Cologni \& Manera, 2008; Ito, 2008; Kargi, 2014; Kiptui, 2009). Supporting these studies, Jalles (2009) also found that oil price shock in 1973 and 1979 expanded inflation in small open economies. On the contrary, Evans \& Fisher (2011), Jiranyakul (2015), and Chen \& Wen (2011) have failed to find any relationship between oil price and core inflation in the case of the USA and Thailand. Hooker's (2002) findings give time-specific results, i.e., before the 1980s, oil price shocks had a great contribution to core inflation in the US economy, whereas, after the 1980s, its magnitude was substantially reduced.

In the case of Asian EMEs, Chou \& Tseng (2011) found a long-term relationship between oil price and CPI but failed to find a significant relationship for short-term periods. On the contrary, Cunado \& Gracia (2005) found that the impact of oil price shock is asymmetric and is only limited to short periods. This asymmetry was further confirmed by Ibrahim (2015) with the help of a Non-linear ARDL model, which established a unidirectional, positive correlation between oil price and food prices for the long-term. However, the oil price fall did not exert any impact on the price level. This absence of significant impact in short-run maybe because of the strong monetary policy actions, economic integration and use of energy-efficient technology in the production process (Álvarez, Hurtado, Sánchez, \& Thomas, 2011). Osawa (2006) further noted that administrative pricing policy and strong monetary policy have a key role in the management of oil price pass-through to inflation.

Uncertainty in the exchange rate behaviour and its negative impact on investment decisions can cause an output loss, which can induce a price level rise (Dixit, 1989; Krugman, 1986). These arguments are substantiated by Bleaney \& Francisco (2007) with the help of data from 41 developing economies. They found a strong positive association between real exchange rate and inflation level. Barro \& Gordon (1983) also found that exchange rate shocks influence the mean and standard deviation of economic output, thus transferring its impact to the price level. 
The impact of exchange rate volatility on CPI was modest in OECD countries (McCarthy, 2007). But in EMEs like Brazil, the adoption of the floating regime accelerated inflation (Blejer, Leone, Rabanal, \& Schwartz, 2002). By analysing data from 71 countries, Goldfajn \& Werlang (2000) also found that devaluation brings inflation into the economy. Ito \& Sato (2008) found that the exchange rate passthrough effect to CPI in Indonesia was high, but it was negligible for Korea, Malaysia, Thailand, and the Philippines. In China, RMB appreciation negatively influenced output and inflation (Chen \& Li, 2013). However, such negative effects on output may have caused the demand-pull inflation in the Chinese economy. The absence of capital mobility, illiquid forward market, and proper hedging instruments intensify the exchange rate pass-through effect in EMEs (Calvo \& Reinhart, 2000).

Earlier studies were more focused on the industrialised economies. However, greater consideration is given to transition economies, especially Asian economies, during the last few decades (see Ghosh \& Rajan, 2007). In the case of India, only a limited number of studies examined the impact of oil price and exchange rate on inflation. Despite a spike in the literature on inflation pass-through effect in the EMEs, academic studies on the Indian scenario is limited. But they too reflect the inconclusive debate about the potential impact of global macroeconomic variables, especially exchange rate and oil price, on inflation. For instance, empirical examination of the dynamics between oil-price and inflation during 1970-1971 to 2005-2006 by Ghosh (2009) contradicted the theoretical argument that international oil price shocks influence the price of petroleum products. According to the study, the absence of such a pass-through effect is because of the government's control over petroleum prices. But later, Ghosh (2011) found contradictory results on the oil price pass-through effect for the 2007-2008 period, using a GARCH framework. The study established a symmetric impact of oil-price on the exchange rate, with permanent effect. Bhattacharyya \& Bhattacharya (2001) found that a 20\% increase in oil price caused a 1.3\% hike in inflation from April 1994 to December 2000. FICCI (2005) estimated that the doubling of oil price brings inflation of $7.9 \%$ points. Gregorio, Landerretche, Neilson, Broda, \& Rigobon (2007) found that the impact of oil price doubling on CPI was 5 point from 1965 to 2004. Examining the monthly, time-series data for the period April 1994 to March 2010, Mandal, Bhattacharyya, \& Bhoi (2012) found that frequent price adjustment of some of the petroleum products in line with the international crude oil price amplified the impact of oil price on domestic inflation in India after 2002.

There are contradictory arguments on the relationship between inflation and the exchange rate in the literature related to the Indian scenario. Confirming the exchange rate pass-through effect, Goyal (2014) and Yanamandra (2015) argued that the INR/USD exchange rate fluctuation indirectly influences inflation in the economy. Some researchers argue that a stable exchange rate is not a determinant of low inflation in India, but the monetary policy of RBI determines it (Mohanty \& Bhanumurthy, 2014). Empirical findings of some important studies in Indian context show that exchange rate volatility influences CPI both in short-run and long-run 
(Bhattacharya, Patnaik, \& Shah, 2008; Dash \& Narasimhan, 2011; Ghosh \& Rajan, 2007; Khundrakpam, 2007; Saha \& Zhang, 2012; Saradhi \& Dholakia, 2000).

This study is an attempt to contribute to the literature on the impact of the dynamics of oil price and exchange rate on inflation in India. The current study is unique from the existing literature as it investigates the dynamics of the exchange rate and oil price on inflation. The specific methodological approach to investigate the short-run and long-run dynamics with the help of an ARDL model (which has not been used in earlier studies) also makes it different.

\section{Data and Methodology}

\subsection{Variable Construction and Data}

The present study tries to examine the impact of crude oil prices and the exchange rate on inflation in the case of India. The study utilised the monthly time series data from April 1994 to February 2018. The particular period is chosen due to the adoption of a managed floating regime for the development of the foreign exchange market. In addition to that, RBI authorised full convertibility of Rupee on the current account from 1994 onwards.

This study used the exchange rate, inflation and oil price as variables for developing the empirical model. Irrespective of different measures of inflation, we used the Consumer Price Index (CPI), which represents the cost of a representative basket of goods and services consumed by an average household (Nair, 2014; Sek et al., 2015; Shaari, Hussain, \& Abdullah, 2012). Brent Crude oil, which is a major benchmark price for purchases of oil worldwide, has been used as the proxy for international crude oil prices. The exchange rate is measured as the Indian Rupee (INR)/U.S. Dollar (USD) bilateral exchange rate (monthly average). The descriptions of all the variables are provided in Table 1.

\section{Table 1: Varible definition and source}

\begin{tabular}{|c|c|c|}
\hline Variables & Definitions & Source \\
\hline LCPI & $\begin{array}{l}\text { Natural logarithm of the consumer } \\
\text { price index, index of } 2010=100 \text {, not } \\
\text { seasonally adjusted. }\end{array}$ & $\begin{array}{l}\text { Federal Reserve Bank of Saint Louis } \\
\text { https://fred.stlouisfed.org/series/INDCPIALLMINMEI }\end{array}$ \\
\hline LEXC & $\begin{array}{l}\text { Natural logarithm of Indian Rupee } \\
\text { to one U.S. dollar, not seasonally } \\
\text { adjusted. }\end{array}$ & $\begin{array}{l}\text { Federal Reserve Bank of Saint Louis } \\
\text { https://fred.stlouisfed.org/series/EXINUS }\end{array}$ \\
\hline LOIL & $\begin{array}{l}\text { Natural logarithm of Brent crude } \\
\text { oil spot prices in U.S. dollar per } \\
\text { barrel, not seasonally adjusted. }\end{array}$ & $\begin{array}{l}\text { Federal Reserve Bank of Saint Louis } \\
\text { https://fred.stlouisfed.org/series/POILBREUSDM }\end{array}$ \\
\hline
\end{tabular}

Table (2) highlights the descriptive statistics of all the variables under study. The results indicate that all the series show positive skewness. CPI shows the highest fluctuation, as represented by the standard deviation, followed by OIL and EXC. In addition, all the variables show kurtosis lesser than 3 implying that each variable 
shows platykurtic distribution with asymmetric tails. The Jarque-Bera statistic shows that CPI, EXC as well as OIL, do not follow a normal distribution. Hence, it is essential to transform the series into a natural logarithm to remove the problem of nonnormality and heteroskedasticity.

Table 2: Descriptive analysis of data.

\begin{tabular}{lrrr}
\hline Variables & CPI & EXC & OIL \\
\hline Mean & 84.33 & 47.63 & 53.04 \\
Median & 68.13 & 45.76 & 46.83 \\
Maximum & 163.71 & 68.23 & 133.90 \\
Minimum & 33.14 & 31.37 & 9.80 \\
Std. Dev. & 39.56 & 9.72 & 34.03 \\
Skewness & 0.67 & 0.52 & 0.62 \\
Kurtosis & 2.08 & 2.56 & 2.12 \\
Jarque-Bera & $31.74^{* * *}$ & $15.43^{* * *}$ & $27.72^{* * *}$ \\
\hline Note: $* * *$ and ${ }^{* *}$ denotes the values are significant at $1 \%$ and $5 \%$ significance level, respectively.
\end{tabular}

\subsection{ARDL Model}

We use the robust ARDL model introduced by Pesaran \& Shin (1999), Pesaran, Shin, \& Smith (2001) and Pesaran \& Smith (1998). The reasons for the selection of this model are:

(a) This test is based on a single ARDL equation, rather than on a VAR as in Johansen. Thus it reduces the number of parameters to be estimated (Ghatak \&Siddiki, 2001)

(b) This test is comparatively more efficient in small and finite sample data sizes, as is the case in our study (Haug, 2002).

(c) This test can be applied regardless of whether the regressors in the model are purely I (0), purely I (1), or mutually co-integrated (Odhiambo, 2009).

(d) ARDL representation does not call for symmetry of lag length. Each length can have a different number of lag lengths (Laurenceson \& Chai, 2003).

The basic form of the model is as follows as:

$$
L C P I_{t}=\alpha_{1}+\beta_{1} L E X C_{t}+\beta_{2} L O I L_{t}+\beta_{3} T_{t}+\beta_{4} D U M_{t}+\mu_{t} \cdots
$$

Where $L$ stands for natural logarithm, and the subscript $t$ refers to the time period. $\alpha_{1}$ is the intercept; T is the trend component, while DUM is a dummy variable that denotes the structural break incorporated in the model.

To implement the ARDL model, equation (1) is transformed into the unrestricted error correction model (UECM). UECM of ARDL approach can be written as:

$$
\begin{aligned}
& \Delta L C P I_{t}=a_{1}+\sum_{i=1}^{\rho} a_{2} \Delta L C P I_{t-i}+\sum_{i=0}^{q_{1}} a_{3} \Delta L E X C_{t-i}+\sum_{i=0}^{q_{2}} a_{4} \Delta L O I L_{t-i}+ \\
& \lambda_{1} L C P I_{t-1}+\lambda_{2} L E X C_{t-1}+\lambda_{3} L O I L_{t-1}+\lambda_{4} T+\lambda_{5} D U M+\mu_{t} \cdots
\end{aligned}
$$

Where $a_{1}$ is the drift component, $\rho$ is the maximum lag length of a dependent variable, $q_{1}$ and $q_{2}$ are the maximum lag length of independent variables, $\Delta$ denotes 
the first difference operator, the expression from $\mathrm{a}_{2}-\mathrm{a}_{4}$ with the summation sign depicts the short-run dynamics of the variable. While, on the right-hand side, expression from $\lambda_{1}-\lambda_{3}$ represents long-run dynamics, $\lambda_{4}$ and $\lambda_{5}$ represent trend and dummy variable in the model, and $\mu_{\mathrm{t}}$ is the error term.

The ARDL bound testing procedure follows several steps. In the very first step, one should know the order of integration of each variable to ensure that none of the variables is stationarity at I(2). More specifically, Ouattara (2004) mentioned that ARDL results might not be valid for any data series which is stationary at $\mathrm{I}(2)$ or beyond.

After that, in order to attain the long-run relationship among LCPI, LEXC, and LOIL, the bound testing procedure provided by Pesaran et al. (2001) is used. This bound testing procedure is based on the F-statistics computed through a Wald test. Fstatistics is used to test the null hypothesis $\left(H_{0}\right)$ of no cointegration among the variables against the alternate hypothesis $\left(\mathrm{H}_{1}\right)$ of cointegration among the variables. Two critical values are provided by the Pesaran et al. (2001) for cointegration test, i.e., lower critical value I (0) and upper critical value I(1). I(0) assume there is no cointegration among the variables, whereas $\mathrm{I}(1)$ assume there is cointegration among the variables. When the calculated F-statistics is higher than the upper bound value, then the null hypothesis is rejected (There is cointegration among variables). If in case F-statistics is less than the lower bound value, we don't rule out the null hypothesis (there is no cointegration among variables). When computed F-statistics fall under I( 0 ) and I(1), the results are inconclusive. Once the long-run relationship is confirmed, we use the following equation to estimate the short-run coefficients with the error correction term:

$\Delta L C P I_{t}=\beta_{1}+\sum_{i=1}^{q_{1}} \beta_{2} \Delta L C P I_{t-i}+\sum_{i=0}^{q_{2}} \beta_{3} \Delta L E X C_{t-i}+\sum_{i=0}^{q_{3}} \beta_{4} \Delta L O I L_{t-i}+$ $\beta_{5} T+\beta_{6} D U M+\gamma E C_{t-1}+\mu_{t} \cdots$

$\gamma$ is the parameter of error correction term $\left(E C_{t-1}\right)$ in the model which can be described as how the variables adjust its long term disequilibrium, $E C_{t}$ can also be explained as speed at which dependent variable returns to equilibrium from the changes in independent variables.

Likewise, Hendry (1995), this study followed a general-to-specific modeling approach to estimate the empirical model in an ARDL framework. study used diagnostic tests such as serial correlation, heteroscedasticity and normality tests to ensure the goodness of fit of the estimated model. Furthermore, the study followed the stability test and breakpoint test for the ARDL estimation, as suggested by Pesaran (1997), to ensure the stability of the model. For this purpose, CUSUM and CUSUMQ statistics suggested by Brown, Durbin, \& Evans (1975) were used. 


\section{Results}

\subsection{Unit Root Tests}

Before any time series analysis, one should know the stationary characteristics of the series. A series is said to be stationary if its mean and variance remains constant over time (Hendry, 1995). Otherwise, fitting a regression model based on non-stationary data may lead to spurious results (Granger \& Newbold, 1974). Therefore, following the literature, we first conducted the most commonly used unit root tests : (i) the Augmented Dickey-Fuller (ADF) test; (ii) the Phillips and Perron (PP) test (Dickey \& Fuller, 1981; Phillips \& Perron, 1988). The results reported in Table 3 reveal that the null hypothesis of non-stationarity of data cannot be rejected when the variables are at levels. But transforming the variables into the first difference ensured stationarity.

Table 3. Unit Root Testing

\begin{tabular}{llcccccc}
\hline \multirow{2}{*}{ Variables } & \multicolumn{3}{c}{ ADF } & \multicolumn{3}{c}{ PP } \\
\cline { 2 - 8 } & & \multirow{2}{*}{ Intercept } & $\begin{array}{c}\text { Intercept } \\
\text { \& Trend }\end{array}$ & \multirow{2}{*}{ None } & Intercept & $\begin{array}{c}\text { Intercept } \\
\text { \& Trend }\end{array}$ & \multirow{2}{*}{ None } \\
\hline LCPI & Level & -0.62 & -1.92 & 2.53 & -0.85 & -1.46 & 8.81 \\
& $\Delta$ & $-3.16^{* *}$ & $-3.187^{* *}$ & -1.531 & $-11.32^{* * *}$ & $-11.30^{* * *}$ & -9.03 \\
\hline LEXC & Level & -0.82 & -1.84 & 3.10 & -0.78 & -1.59 & 3.86 \\
& $\Delta$ & $-10.74^{* * *}$ & $-10.73^{* * *}$ & $-10.07^{* * *}$ & $-10.51^{* * *}$ & $-10.49^{* * *}$ & $-9.90^{* * *}$ \\
\hline LOIL & Level & -2.08 & -2.26 & -1.59 & -1.97 & -2.13 & -1.56 \\
& $\Delta$ & $-13.13^{* * *}$ & $-13.14^{* * *}$ & $-13.14^{* * *}$ & $-13.18^{* * *}$ & $-13.18^{* * *}$ & $-13.19^{* * *}$ \\
\hline
\end{tabular}

Source: Author's calculation using Eviews software, version 10

Note: $* * *$ and $* *$ denotes the values are significant at $1 \%$ and $5 \%$ significance level, respectively. The optimum lags in ADF test are selected on Schwarz Information Criteria with a maximum lag length of 20, whereas the Parzen kernel with Newey-West Bandwidth is used for PP test.

\subsection{Breakpoint Unit Root Test}

The conventional unit root tests are biased towards a false acceptance of stationarity when the data exhibits trend stationarity with a structural break. Therefore, researchers estimated structural breaks to ensure the robustness of the series. For this purpose, Perron's (1989) breakpoint unit root test was employed, which accounts for the single unknown break in a series. Following the empirical models of Tursoy (2019), Ahad (2017), Sun, Zheng \& Xu (2017), this study incorporated structural breaks in the model for a better understanding of the order of integration. The results of the Breakpoint Unit Root Test are reported in Table 4, which failed to reject the null hypothesis of non-stationarity of data when the variables are at levels. But after transforming the variables into the first difference, they ensured stationarity. After compensating all the breaks in the models, only 2008M10 was found statistically significant. Therefore, we incorporated 2008M10 as a dummy variable in the model. This period was crucial for all variables because of the impact 
of global financial crisis in 2008, especially on factors like exchange rate and crude oil price (Khan, 2017).

\section{Table 4. Breakpoint Unit Root Test}

\begin{tabular}{lcccc}
\hline & \multicolumn{2}{c}{ At Levels } & \multicolumn{2}{c}{ At First Difference } \\
Variable & TBs & T-Statistics & TBs & T-Statistics \\
\hline LCPI & $2008 \mathrm{M} 01$ & $-2.499[15]$ & $1998 \mathrm{M} 10$ & $-10.348^{* * *}[15]$ \\
LEXC & $2011 \mathrm{M} 07$ & $-3.583[15]$ & $2008 \mathrm{M} 10$ & $-12.697^{* * *}[15]$ \\
LOIL & $2003 \mathrm{M} 09$ & $-3.215[15]$ & $2008 \mathrm{M} 10$ & $-14.209 * * *[15]$ \\
\hline
\end{tabular}

Source: Author's calculation using Eviews software, version 10

Note: $* * *$ and $* *$ denotes the values are significant at $1 \%$ and $5 \%$ significance level, respectively. The break type is an innovational outlier, and the breakpoint is selected by Dickey-Fuller min-t method, the maximum lag length is set at 15 based on Schwarz Information Criteria; TBs stands for test breaks at level and first difference.

\subsection{ARDL Lag Selection}

Recognising the fact that selecting the optimal lag length is an arduous task as sometimes under-fitting and over-fitting of the lag length creates the autocorrelation problem and unnecessarily increases the mean squared forecast error (Lütkepohl, 1993). This problem can easily be sorted out by choosing appropriate lag length based on different criteria provided in the literature like Akaike (AIC), Schwarz (SC), and Hannan-Quinn (HQ).

Based on the argument of Gutierrez, Souza \& Guillen (2009) and Liew (2004) we choose AIC criteria for optimum lag order of the ARDL $\left(p, q_{1}, q_{2}\right)$ as it produces better and consistent results than other information criteria. Figure 1 reports the top 20 models out of the 972 different ARDL models evaluated by E-views. Out of the available combinations, we choose $\operatorname{ARDL}(8,2,0)$ model with 8 lags of LCPI (dependent variable), 2 lags and 0 lags of LEXC and LOIL (independent variables).

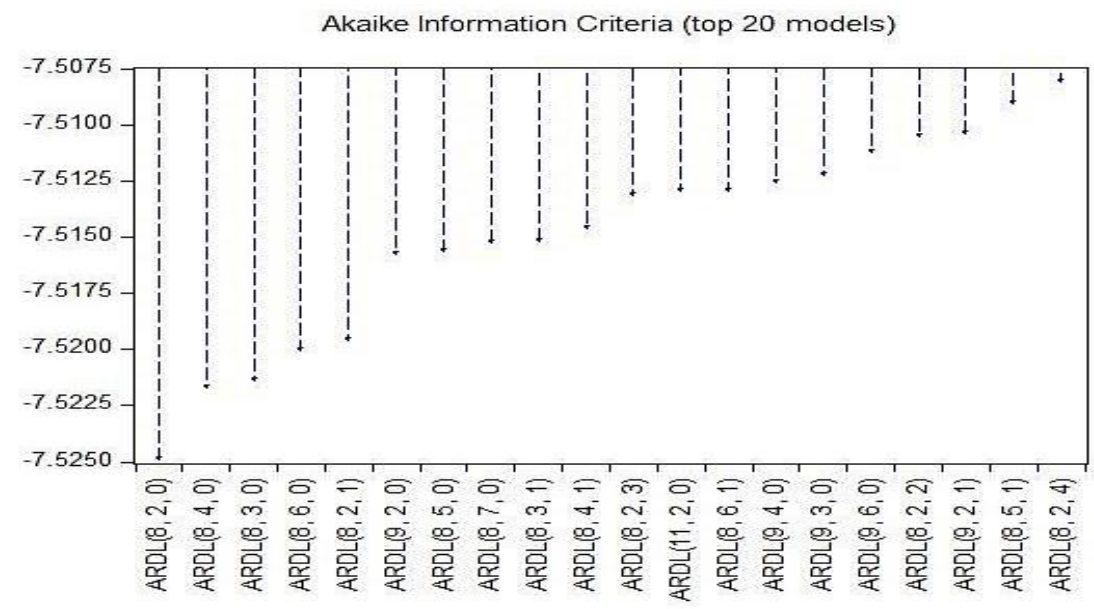

Figure 1. ARDL Lag Length Selection. 


\subsection{Diagnostic Tests for the Model}

The coefficient of determination, $\mathrm{R}^{2}$, is acceptable, explaining $99 \%$ of the variation in LCPI is explained by the independent variables and rest by the error term. The Durbin-Watson statistics is 2.03 , which confirms that the model is not spurious. As illustrated in Table 5, the model passes diagnostic tests for auto-correlation (Breusch-Godfrey Serial Correlation LM test), normality (Jarque-Bera test), and heteroskedasticity (Breusch-Pagan-Godfrey Heteroskedasticity test) as well.

\section{Table 5. Model Diagnostic Tests Results}

\begin{tabular}{lcc}
\hline Test & $\chi^{\mathbf{2}}$ & Probability \\
\hline Breusch-Godfrey Serial Correlation LM Test & 0.5528 & 0.7585 \\
Breusch-Pagan-Godfrey Heteroskedasticity Test & 19.6988 & 0.1399 \\
Jarque-Bera Test & 2.382 & 0.3038 \\
R-Square & \multicolumn{2}{c}{0.999} \\
Adjusted R-Square & \multicolumn{2}{c}{0.998} \\
\hline
\end{tabular}

Source: Author's calculation using Eviews software, version 10

\subsection{ARDL Bound Test Results}

To investigate the existence of the long-run relationship among variables, we estimate equation (2) by Ordinary Least Square (OLS) estimation procedure. The joint F-statistics or Wald statistics were computed with the null hypothesis of $\mathrm{H}_{0}$ : $\lambda_{1}=\lambda_{2}=\lambda_{3}=0$ against the alternate hypothesis $\mathrm{H}_{\mathrm{A}}: \lambda_{1} \neq \lambda_{2} \neq \lambda_{3} \neq 0$. The value of the F-statistics (Table 6.) exceeds the upper bound at a $5 \%$ significance level. Thus, the null hypothesis (no cointegration) is rejected, and therefore, it can be concluded that all the variables are significantly different from zero, and a long-run association among LCPI, LEXC, and LOIL exists.

Table 6. Cointegration Bound Test Result

\begin{tabular}{lcccc}
\hline & $\begin{array}{c}\text { Bound test F- Statistics } \\
\text { computed Value }\end{array}$ & \multicolumn{2}{c}{$\begin{array}{c}\text { Bound test F critical } \\
\text { Value at 5\% level }\end{array}$} & Decision \\
\hline \multirow{2}{*}{$L C P I_{\mathrm{t}}=f(L E X C t, L O I L t)$} & $12.702^{* *}$ & $\mathrm{I}(0)$ & $\mathrm{I}(1)$ & Cointegrated \\
\hline
\end{tabular}

Source: Author's calculation using Eviews software, version 10

Note: (1) The bound test F-statistics results are obtained from Pesaran, Shin, \& Smith, $289-326,2001$ ).

Case V- unrestricted intercept and unrestricted trend $(2)^{* *}$ denotes significant at $5 \%$ alpha level.

\subsection{Long-Run and Short-Run Results}

All the long-run variables are statistically significant and have an expected sign, as shown in Table 7. The estimated coefficients of exchange rate (LEXC) and crude oil prices (LOIL) have positive sign showing that $10 \%$ depreciation of exchange rate will increase inflation by $2.4 \%$ and a similar $10 \%$ hike in crude oil prices will increase the inflation by $1.2 \%$ in the long-run, the results are significant with the findings of Bhattacharya et al. (2008) and Khundrakpam (2007). 
Table 7. Estimated Long-Run Coefficients using the ARDL Approach.

\begin{tabular}{lcccc}
\hline Variable & Coefficient & Std. Error & t-Statistic & Prob. \\
\hline Constant & 0.157 & 0.044 & 3.528 & $0.000^{* * *}$ \\
LEXC & 0.242 & 0.087 & 2.761 & $0.000^{* * *}$ \\
LOIL & 0.121 & 0.036 & 3.277 & $0.001^{* * *}$ \\
T & 0.001 & 6.310 & 2.589 & $0.010^{* *}$ \\
DUM & 0.096 & 0.019 & 5.019 & $0.000^{* * *}$ \\
\hline
\end{tabular}

Source: Author's calculation using Eviews software, version 10

Note: $* * * * * * *$ denotes significant at $1 \%, 5 \%$ and $10 \%$ alpha level.

Long-run estimation results conclude that the rupee exchange rate and crude oil prices do affect inflation. It shows the presence of a high pass-through effect in the case of India. After estimating long-run coefficients, we estimated the restricted error correction version of ARDL model for understanding the nexus between longrun and short-run equilibrium. The results are presented in Table 8.

Table 8. Error Correction Model (lag order: 8,2,0,1)

\begin{tabular}{lcccc}
\hline Variables & Coefficient & Std. Error & t-Statistic & Prob. \\
\hline Constant & 0.1573 & 0.0240 & 6.5444 & $0.0000^{* * *}$ \\
$\Delta \mathrm{LCPI}_{\mathrm{t}-1}$ & 0.1700 & 0.0600 & 2.8321 & $0.0051^{* * *}$ \\
$\Delta \mathrm{LCPI}_{\mathrm{t}-2}$ & -0.1653 & 0.0560 & -2.9505 & $0.0035^{* * *}$ \\
$\Delta \mathrm{LCPI}_{\mathrm{t}-4}$ & -0.1368 & 0.0535 & -2.5546 & $0.0114^{* *}$ \\
$\Delta \mathrm{LCPI}_{\mathrm{t}-5}$ & -0.1980 & 0.0544 & -3.6377 & $0.0003^{* * *}$ \\
$\Delta \mathrm{LCPI}_{\mathrm{t}-6}$ & 0.1128 & 0.0549 & 2.0531 & $0.0413^{* *}$ \\
$\Delta \mathrm{LCPI}_{\mathrm{t}-\mathrm{t}}$ & -0.3434 & 0.0536 & -6.4073 & $0.0000^{* * *}$ \\
$\Delta \mathrm{LEXC}$ & 0.1783 & 0.0210 & 8.4598 & $0.0000^{* * *}$ \\
$\Delta \mathrm{LEXC}_{\mathrm{t}-1}$ & -0.0618 & 0.0234 & -2.6378 & $0.0090^{* * *}$ \\
$\mathrm{~T}$ & 0.0001 & $3.24 \mathrm{E}-05$ & 5.0428 & $0.0000^{* * *}$ \\
DUM & 0.0964 & 0.0017 & 5.5229 & $0.0000^{* * *}$ \\
$\mathrm{ECT}$ & -0.2529 & 0.0085 & -6.2034 & $0.0000^{* * *}$ \\
\hline SOUT: & &
\end{tabular}

Source: Author's calculation using Eviews software, version 10

Note: ${ }^{* * * * * * *}$ denotes significant at $1 \%, 5 \%$ and $10 \%$ level of significance.

As illustrated in Table 8, the sign of the estimated one period lagged error correction term (ECT $\left.\mathrm{t}_{-1}\right)$ is negative and also highly significant at the $1 \%$ level. It indicates that the system is getting adjusted towards long-run equilibrium at a speed of $25.2 \%$ in one period (one month). Banerjee et al. (1998) state that a significant ECT is further proof of the existence of a stable long-run relationship. In short-run also, exchange rate and crude oil prices significantly affect inflation at $1 \%$ significance level.

\subsection{Stability Diagnostics}

Further, the cumulative sum of recursive residuals (CUSUM) means plot in Figure (2), and the cumulative sum of square (CUSUMQ) variance plotted in Figure (3) is employed to test the stability of the model with the ECT term. The results indicate the absence of any instability of the coefficients as the plot of the CUSUM and 
Measuring the Impact of Oil Prices, Exchange Rate Shocks on Inflation: Evidences from India CUSUMQ statistic falls inside the critical boundary lines at the $5 \%$ level of significance.

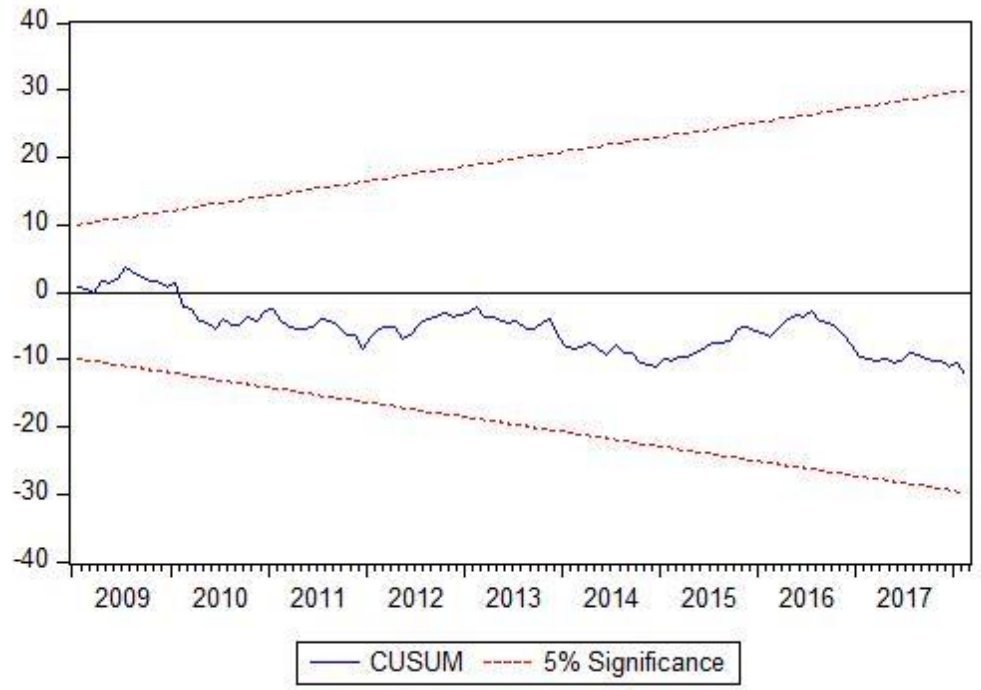

Figure 2. CUSUM

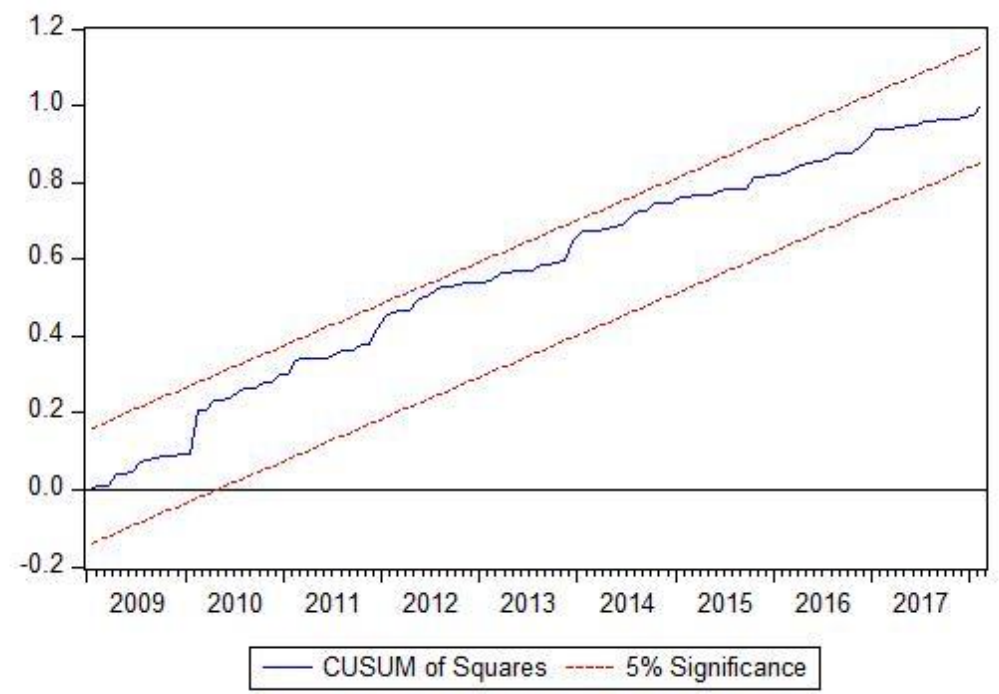

Figure 3. CUSUMQ 


\subsection{Discussion}

The results of our study show a significant impact of exchange rate volatility and oil price fluctuation on CPI in India. Similar results were found in other economies also. For instance, (Castro, Jiménez-Rodríguez, Poncela, \& Senra, 2017) found that oil price shocks worsen inflation in European economies. Choi et al. (2018) also discovered a similar result with an asymmetric effect in different developed and developing economies. Theoretically, it is justified that an unexpected increase in oil prices forces the customers to substantially reduce the expenditure on non-energy goods and services, offsetting the effect. However, it may not be feasible in rapidly developing economies because of the huge gap in demand and supply of the resources. This may be the reason for the positive impact of the exchange rate and oil price on CPI in India. Following the findings of Chen (2009) and Sek (2017), domestic currency appreciation, active monetary policy actions and a higher degree of trade openness make the impact negligible in developing economies. The absence of such a condition may worsen inflation.

Edelstein \& Kilian (2009) argued that oil price fluctuation directly influences energy inflation only, and it transfers to consumers through the cost of products. If the proportion of energy inflation in core inflation is minimal, the degree of pass-through effect to the CPI will also be negligible and vice versa. Energy inflation has a vital portion in CPI basket in the Indian scenario, as the country is energy-dependent. Our results substantiate this argument. Similarly, the impact of exchange rate volatility also contributes to domestic inflation. In the first stage, it influences the import prices. It transmits to the general price level in the second stage. This impact will be severe if the countries import necessary goods and inputs for the production process is less substitutable. This creates huge trade deficit and Balance of Payment (BOP) crisis. Alternatively, the government policies should be capable enough to bring down the degree of such transfer from the first stage to second, so that the effect will be minimal. In India, the practice of oil subsidies, control on the retail price and fuel tax control have a significant role in the determination of the degree of transmission of oil price shocks to inflation. Similarly, monetary policy actions of RBI are effective in controlling the transmission of exchange rate volatility to CPI and WPI. But the high degree of energy demand and high volatility of the exchange rate may cause the failure of policy actions in some episodes.

\section{Conclusion}

The rapid development of EMEs boosted the demand for foreign exchange and crude oil in the global economy, which in turn influenced the price of these products. This study attempted to examine the theoretical arguments of impact of exchange rate and oil price shock on domestic inflation, from a different thoretical framework. The results disclose that fluctuations in the oil price and exchange rate have a positively significant influence on inflation both in long-run and short-run. The empirical model was found to be qualifying the standard diagnostic tests of Heteroskedasticity, Serial 
Correlation and Normality. Further, the CUSUM mean and CUSUMQ variance plot confirmed that all the coefficients in the ECM model are stable.

From the theoretical point of view, oil price fluctuation has a large impact on energy inflation, whereas its impact on total inflation is negligible in India. This is because of the negligible proportion of energy in the total inflation and hedging capacity of nonenergy items over energy items. Failure of these conditions will make inflation worse in oil-importing countries including India. The typical characteristic of the Indian economy, where a policy of subsidised petroleum products and administrative pricing is employed to reduce the proportion of energy inflation in total inflation, is reflected in the results. This may be the reason for the minimal impact of oil prices over the exchange rate on inflation. However, the rapid depreciation of Rupee influenced inflation through import prices, and its magnitude was high during the study period. Recent foreign exchange reserve accumulation to prevent appreciation, which expanded the monetary base, also worsened the inflation scenario. Despite the accelerated capital inflow, development of the money market, and economic reforms, the monetary authority failed to manage Rupee volatility in India. It has also contributed to the inflation situation. In the long-run, oil price and exchange rate shocks increased the cost of production, influenced the cost competitiveness, and thus affected the profitability of the firms. But the impact of such shocks can be hedged for the short-run in India with the help of cheap labour availability. This may not be viable for the long-run. However, the adoption of an inflation-targeting policy with a secondary emphasis on curbing exchange rate volatility may help the country to manage inflation effectively.

\section{References}

Abounoori, A. A., Nazarian, R., \& Amiri, A. (2014). Oil Price Pass-Through into Domestic Inflation: The Case of Iran. International Journal of Energy Economics and Policy, 4(4), 662669.

Ahad, M. (2017). Impact of financial development on trade balance: An ARDL cointegration and causality approach for Pakistan. Global Business Review, 18(5), 1199-1214. https://doi.org/10.1177/0972150917710152

Álvarez, L. J., Hurtado, S., Sánchez, I., \& Thomas, C. (2011). The impact of oil price changes on Spanish and euro area consumer price inflation. Economic Modelling, 28(1-2), 422-431. http://doi.org/10.1016/j.econmod.2010.08.006

Banerjee, A., Dolado, J., \& Mestre, R. (1998). Error-Correction Mechanism Tests for Cointegration in a Single-Equation Framework. Journal of Time Series Analysis, 19(3), 267-83. http://doi.org/10.1111/1467-9892.00091.

Barro, R. J., \& Gordon, D. B. (1983). A Positive Theory of Monetary Policy in a Natural Rate Model. Journal of Political Economy, 91(4), 589-610. http://doi.org/10.1086/261167

Bhattacharya, K., \& Bhattacharyya, I. (2001). Impact of increase in oil prices on inflation and output in India. Economic and Political weekly, 4735-4741. 
Bhattacharya, R., Patnaik, I., \& Shah, A. (2008). Exchange rate pass-through in India. New Delhi: National Institute of Public Finance and Policy.

Blanchard, O. J., \& Gali, J. (2007). The Macroeconomic Effects of Oil Shocks: Why are the 2000s so different from the 1970s? (No. w13368). National bureau of economic research. http://dx.doi.org/10.3386/w13368

Blanchard, O. J., \& Riggi, M. (2013). why are the 2000s so Different from the 1970 s? a Structural Interpretation of Changes in the Macroeconomic Effects of Oil Prices. Journal of the European Economic Association, 11(5), 1032-1052. http://doi.org/10.1111/jeea.12029

Bleaney, M., \& Francisco, M. (2007). Exchange Rate Regimes, Inflation and Growth in Developing Countries -- An Assessment. The B.E. Journal of Macroeconomics, 7(1), 1-18. http://doi.org/10.2202/1935-1690.1546

Blejer, M. I., Leone, A. M., Rabanal, P., \& Schwartz, G. (2002). Inflation targeting in the context of IMF-supported adjustment programs. IMF Staff Papers, 49(3), 313-338. http://doi.org/10.2307/3872500

Brown, R. . L. ., Durbin, J., \& Evans, J. . . (1975). Techniques for Testing the Constancy of Regression Relationships over Time. Journal of the Royal Statistical Society, 37(2), 149-192. http://dx.doi.org/10.1111/j.2517-6161.1975.tb01532.x

Calvo, G. A., \& Reinhart, C. M. (2000). Fixing for your life (No. w8006). National Bureau of Economic Research. http://dx.doi.org/10.3386/w8006

Castro, C., Jiménez-Rodríguez, R., Poncela, P., \& Senra, E. (2017). A new look at oil price passthrough into inflation: evidence from disaggregated European data. Economia Politica, 34(1), 55-82. http://doi.org/10.1007/s40888-016-0048-9

Chen, M. \& Wen, Y. (2011). Oil price shocks and inflation risk. Economic SYNOPSES Short Essays and Reports on the Economic Issues of the Day, (19). http://dx.doi.org/10.20955/es.2011.19

Chen, S.-S. (2009). Oil price pass-through into inflation. Energy Economics, 31(1), 126-133. http://doi.org/10.1016/i.eneco.2008.08.006

Chen, Y., \& Li, D. (2013). RMB Appreciation, Output Growth, and Inflation. Economic and Political Studies, 1(2), 3-17. http://doi.org/10.1080/20954816.2013.11673857

Choi, S., Furceri, D., Loungani, P., Mishra, S., \& Poplawski-Ribeiro, M. (2018). Oil prices and inflation dynamics: Evidence from advanced and developing economies. Journal of International Money and Finance, 82, 71-96. http://doi.org/10.1016/j.jimonfin.2017.12.004

Chou, K. W., \& Tseng, Y. H. (2011). Oil price pass-through into CPI inflation in Asian emerging countries: the discussion of dramatic oil price shocks and high oil price periods. Journal of Economics Finance and Management Sciences, 2(1), 1-13.

Cologni, A., \& Manera, M. (2008). Oil prices, inflation and interest rates in a structural cointegrated VAR model for the G-7 countries. Energy Economics, 30(3), 856-888. http://doi.org/10.1016/j.eneco.2006.11.001

Cunado, J., \& Gracia, F. P. de. (2005). Oil prices, economic activity and inflation: evidence for some Asian countries. The Quarterly Review of Economics and Finance, 45(1), 65-83. http://doi.org/10.1016/j.qref.2004.02.003

Dash, A. K., \& Narasimhan, V. (2011). Exchange Rate Pass-through How Much Do Exchange Rate Changes Affect the Prices of Indian Exports and Imports. South Asia Economic Journal, 


\section{2(1), 1-23. http://doi.org/10.1177/139156141001200101}

Dickey, D. A., \& Fuller, W. A. (1981). Likelihood ratio statistics for autoregressive time series with a unit root. Econometrica: Journal of the Econometric Society, 49(4), 1057-1072. http://dx.doi.org/10.2307/1912517

Dixit, A. (1989). Hysteresis, Import Penetration, and Exchange Rate Pass-Through. The Quarterly Journal of Economics, 104(2), 205. http://doi.org/10.2307/2937845

Domaç, I., \& Yücel, E. M. (2005). What triggers inflation in emerging market economies?. Review of world economics, 141(1), 141-164. https://doi.org/10.1596/18139450-3376

Edelstein, P., \& Kilian, L. (2009). How sensitive are consumer expenditures to retail energy prices? Journal of Monetary Economics, 56(6), 766-779. http://doi.org/10.1016/j.jmoneco.2009.06.001

Evans, C. L., \& Fisher, J. D. M. (2011). What are the implications of rising commodity prices for inflation and monetary policy? Chicag-o Fed Letter.

FICCI, F. of I. C. of C. and I. (2005). Impact of high oil prices on Indian economy.

Ghatak, S., \& Siddiki, J. U. (2001). The use of the ARDL approach in estimating virtual exchange rates in India. Journal of Applied statistics, 28(5), 573-583. http://dx.doi.org/10.1080/02664760120047906

Ghosh, A., \& Rajan, R. S. (2007). A Survey of Exchange Rate Pass-Through in Asia. Asian-Pacific Economic Literature, 21(2), 13-28.http://doi.org/10.1111/j.1467-8411.2007.00199.x-i1

Ghosh, S. (2009). Import demand of crude oil and economic growth: Evidence from India. Energy Policy, 37(2), 699-702. http://doi.org/10.1016/i.enpol.2008.10.021

Ghosh, S. (2011). Examining crude oil price - Exchange rate nexus for India during the period of extreme oil price volatility. Applied Energy, 88(5), 1886-1889. http://doi.org/10.1016/j.apenergy.2010.10.043

Ghosh, T. (2016). Oil Price, Exchange Rate and the Indian Macroeconomy. Economic and Political Weekly, 51(40).

Goldfajn, I., \& Werlang, S. R. D. C. (2000). The pass-through from depreciation to inflation: a panel study. Werlang, Sergio R., The Pass-Through from Depreciation to Inflation: A Panel Study (July 2000). Banco Central de Brasil Working Paper, (5). http://dx.doi.org/10.2139/ssrn.224277

Goyal, A. (2014). History of monetary policy in India since independence. Springer Briefs in Economics. New Delhi: Springer. http://dx.doi.org/10.1007/978-81-322-1961-3 2

Granger, C. W., \& Newbold, P. (1974). Spurious regressions in econometrics. Journal of Econometrics, 2(2), 111-120. http://dx.doi.org/10.1016/0304-4076(74)90034-7

Gregorio, J. De, Landerretche, O., Neilson, C., Broda, C., \& Rigobon, R. (2007). Another Passthrough Bites the Dust? Oil Prices and Inflation. Economía, 7(2), 155-208. http://dx.doi.org/10.1353/eco.2007.0014

Gupta, P., \& Goyal, A. (2015). Impact of oil price fluctuations on Indian economy. OPEC Energy Review, 39(2), 141-161. http://doi.org/10.1111/opec.12046

Gutierrez, C. E. C., Souza, R. C., \& Guillén, O. T. D. C. (2009). Selection of Optimal Lag Length in Cointegrated VAR Models with Weak Form of Common Cyclical Features. Brazilian Review of Econometrics, 29(1). http://dx.doi.org/10.12660/bre.v29n12009.2696 
Haug, A. (2002). Temporal aggregation and the power of cointegration tests: A Monte Carlo study. Oxford Bulletin of Economics and Statistics, 64, 399-412. http://dx.doi.org/10.1111/1468-0084.00025

Hendry, D. F. (1995). Dynamic Econometrics. Oxford University Press. http://dx.doi.org/10.1093/0198283164.001.0001

Hooker, M. A. (2002). Are Oil Shocks Inflationary? Asymmetric and Nonlinear Specifications versus Changes in Regime. Journal of Money, Credit and Banking, 34(2), 540-561.

Ibrahim, M. H. (2015). Oil and food prices in Malaysia: a nonlinear ARDL analysis. Agricultural and Food Economics, 3(1), 2. http://doi.org/10.1186/s40100-014-0020-3

IPNG. (2017). Indian Petroleum \& Natural Gas Statistics 2016-17. Retrieved from http://petroleum.nic.in/sites/default/files/pngstat_1617r_0.pdf

Ito, K. (2008). Oil Prices and Macro-economy in Russia: The Co-integrated VAR Model Approach. International Applied Economics and Management Letters, 1(1), 37-40.

Ito, T., \& Sato, K. (2008). Exchange Rate Changes and Inflation in Post-Crisis Asian Economies: Vector Autoregression Analysis of the Exchange Rate Pass-Through. Journal of Money, Credit and Banking, 40(7), 1407-1438. http://doi.org/10.1111/j.1538-4616.2008.00165.x

Jalles, J. T. (2009). Do Oil Prices Matter? The Case of a Small Open Economy. Annals of Economics and Finance, 10(1), 65-87.

Jin, G. (2008). The impact of oil price shock and exchange rate volatility on economic growth: A comparative analysis for Russia, Japan, and China. Research Journal of International Studies, 8(11), 98-111.

Jiranyakul, K. (2015). Oil Price Shocks and Domestic Inflation in Thailand. SSRN Electronic Journal. http://doi.org/10.2139/ssrn.2578836

Kargi, B. (2014). The Effects of Oil Prices on Inflation and Growth: Time Series Analysis in Turkish Economy . International Journal of Economics and Research, 5(2), 29-36.

Khan, M. I. (2017). Falling oil prices: Causes, consequences and policy implications. Journal of Petroleum Science and Engineering, 149, 409-427. http://doi.org/10.1016/i.petrol.2016.10.048

Khullar, V. (2018). What impacts petroleum prices? Retrieved from http://www.prsindia.org/theprsblog/?p=4081

Khundrakpam, J. K. (2007). Economic reforms and Exchange Rate pass-through to domestic prices in India. (No. 225.). Bank for International Settlements. http://dx.doi.org/10.2139/ssrn.1012584

Kiptui, M. (2009). Oil Price Pass-Through into Inflation in Kenya. Kenya School of Monetary Studies Research Centre, Nairobi.

Krugman, P. (1986). Pricing to Market when the Exchange Rate Changes. Cambridge, MA. http://dx.doi.org/10.3386/w1926

Laurenceson, J., \& Chai, J. C. (2003). Financial reform and economic development in China. Edward Elgar Publishing. http://dx.doi.org/10.2307/3182162

Liew, V. K. (2004). Which Lag Length Selection Criteria Should We Employ? Economics Bulletin., 3(33), 1-9.

Lütkepohl, H. (1993). Testing for Causation Between Two Variables in Higher-Dimensional VAR Models. In Studies in Applied Econometrics, 75-91. http://doi.org/10.1007/978-3-642-51514- 
Measuring the Impact of Oil Prices, Exchange Rate Shocks on Inflation: Evidences from India

\section{4}

Mandal, K., Bhattacharyya, I., \& Bhoi, B. B. (2012). Is the oil price pass-through in India any different? Journal of Policy Modeling, 34(6), 832-848. http://doi.org/10.1016/j.jpolmod.2012.06.001

McCarthy, J. (2007). Pass-Through of Exchange Rates and Import Prices to Domestic Inflation in Some Industrialized Economies. Eastern Economic Journal, 33(4), 511-537. http://doi.org/10.1057/eej.2007.38

McKillop, A. (2004). Oil prices, economic growth and world oil demand. Middle East Economic Survey, 47(35).

Mohanty, B., \& Bhanumurthy, N. R. (2014). Exchange Rate Regimes and Inflation: Evidence from India. International Economic Journal, 28(2), 311-332. http://doi.org/10.1080/10168737.2014.905618

Nair, M. S. (2014). Inflation Dynamics in India: An Analysis (No. 57110). University Library of Munich, Germany.

Neely, C. J., \& Rapach, D. E. (2011). International comovements in inflation rates and country characteristics. Journal of International Money and Finance, 30(7), 1471-1490. http://doi.org/10.1016/j.jimonfin.2011.07.009

Odhiambo, N. M. (2009). Energy consumption and economic growth nexus in Tanzania: An ARDL bounds testing approach. Energy Policy, 37(2), 617-622. http://dx.doi.org/10.1016/i.enpol.2008.09.077

Onoh, J. K. (2017). The Nigerian oil economy: From prosperity to glut. Routledge. http://dx.doi.org/10.4324/9781315142982-5

Osawa, N. (2006). Monetary Policy Responses to the Exchange Rate: Empirical Evidence from Three East Asian Inflation-Targeting Countries (Bank of Japan Working Paper Series No. 6$\mathrm{NaN}$-14). Bank of Japan.

Ouattara, B. (2004). Modelling the Long Run Determinants of Private Investment in Senegal. Centre for Research in Economic Development and International Trade, 44(0), 37. http://doi.org/10.5539/ass.v8n13p139

Peersman, G. (2011). Macroeconomic effects of unconventional policy in the euro area. European Central Bank. Retrieved from www.ssrn.com/abstract_id=1934167

Perron, P. (1989). The great crash, the oil price shock, and the unit root hypothesis. Econometrica: Journal of the Econometric Society, 1361-1401. https://doi.org/10.2307/1913712

Pesaran, H. (1997). The Role of Economic Theory in Modelling the Long Run. The Economic Journal, 107(440), 178-191. https://doi.org/10.1111/1468-0297.00151

Pesaran, M. H., \& Shin, Y (1999). An autoregressive distributed lag modelling approach to cointegration analysis in Strom. In S. Strom (Ed.), Econometrics and Economic Theory in the 20th Century: The Ragnar Frisch ... (p. 371-413.). Cambridge: Cambridge University Press/ http://doi.org/10.1017/CCOL521633230.011

Pesaran, M. H., \& Smith, R. P. (1998). Structural Analysis of Cointegrating VARs. Journal of Economic Surveys, 12(5), 471-505. http://doi.org/10.1111/1467-6419.00065

Pesaran, M. H., Shin, Y., \& Smith, R. J. (2001). Bounds testing approaches to the analysis of level relationships. Journal of Applied Econometrics, 16(3), 289-326. http://doi.org/10.1002/jae.616 
Phillips, P. C., \& Perron, P. (1988). Testing for a unit root in time series regression. Biometrika, 75(2), 335-346. https://doi.org/10.1093/biomet/75.2.335

Rautava, J. (2004). The role of oil prices and the real exchange rate in Russia's economy-a cointegration approach. Journal of Comparative Economics, 32(2), 315-327. http://doi.org/10.1016/i.jce.2004.02.006

Saha, S., \& Zhang, Z. (2016). Exchange Rate Pass-Through and Inflation in Australia, China and India: A Comparative Study with Disaggregated Data. Journal of Economic Research, 21, 1-9. Retrieved from http://eprints.lincoln.ac.uk/22833/7/JER2016.pdf

Saradhi, R. V, \& Dholakia, R. H. (2000). Exchange Rate Pass-Through and Volatility: Impact on Indian Foreign Trade. Economic and Political Weekly, 35(47), 4109-4116.

Sek, S. K. (2017). Impact of oil price changes on domestic price inflation at disaggregated levels: Evidence from linear and nonlinear ARDL modeling. Energy, 130, 204-217. http://doi.org/10.1016/i.energy.2017.03.152

Sek, S. K., Teo, X. Q., \& Wong, Y. N. (2015). A Comparative Study on the Effects of Oil Price Changes on Inflation. Procedia Economics and Finance, 26, 630-636. http://doi.org/10.1016/S2212-5671(15)00800-X

Senadza, B., \& Diaba, D. D. (2017). Effect of exchange rate volatility on trade in Sub-Saharan Africa. Journal of African Trade, 4(1-2), 20-36. http://doi.org/10.1016/i.jo at.2017.12.002

Shaari, M. S., Hussain, N. E., \& Abdullah, H. (2012). The Effects of Oil Price Shocks and Exchange Rate Volatility on Inflation: Evidence from Malaysia. International Business Research, 5(9). http://doi.org/10.5539/ibr.v5n9p106

Shahbaz, M., Mallick, H., Mahalik, M. K., \& Sadorsky, P. (2016). The role of globalization on the recent evolution of energy demand in India: Implications for sustainable development. Energy Economics, 55, 52-68. http://doi.org/10.1016/j.eneco.2016.01.013

Sun, C., Zhang, F., \& Xu, M. (2017). Investigation of pollution haven hypothesis for China: an ARDL approach with breakpoint unit root tests. Journal of cleaner production, 161, 153-164. https://doi.org/10.1016/i.jclepro.2017.05.119

Tursoy, T. (2019). The interaction between stock prices and interest rates in Turkey: empirical evidence from ARDL bounds test cointegration. Financial Innovation, 5(1), 7. http://dx.doi.org/10.1186/s40854-019-0124-6

Yanamandra, V. (2015). Exchange rate changes and inflation in India: What is the extent of exchange rate pass-through to imports? Economic Analysis and Policy, 47, 57-68. http://doi.org/10.1016/j.eap.2015.07.004 